\title{
Lung cancer in the meat industry
}

\author{
D COGGON, B PANNETT, E C PIPPARD, P D WINTER
}

From the MRC Environmental Epidemiology Unit, University of Southampton, Southampton General Hospital, Southampton SO9 $4 X Y, U K$

ABSTRACT Routine statistics of occupational mortality and incidence of cancer have consistently $\vec{P}$ shown high rates of lung cancer in butchers. Possible explanations include infection by carcinogenic papilloma viruses, exposure to polycyclic aromatic hydrocarbons and nitrites in the preservation of meat, or a confounding effect of tobacco. To explore these possibilities, we have examined the mortality of 1610 men employed at three British companies processing pork, beef, lamb, bacon, and $\mathrm{\beta}$ other meat products. The overall death rate was less than in the national population (271 deaths observed, 310 expected) but there was an excess of deaths from cancer ( 87 observed, 80 expected), and ${ }_{-}^{\omega}$ in particular from lung cancer ( 42 observed, 32 expected). The risk of lung cancer was concentrated in $\vec{b}_{\infty}^{\circ}$ subjects exposed to recently slaughtered meat, especially after an interval of 10 or more years. Theseo findings increase suspicions of a risk of lung cancer in butchers, although further information is needed about smoking habits in the meat industry. If there is a hazard infection by a papilloma virus would seem the most likely cause.

Analyses of routinely collected data on occupational mortality and incidence of cancer from England and Wales, ${ }^{1-3}$ Denmark, ${ }^{14}$ and Sweden ${ }^{1}$ have consistently shown high rates of lung cancer among butchers and slaughtermen. This excess might be due to infection by papilloma viruses. ${ }^{5}$ Human papilloma virus DNA sequences have recently been found in biopsies of invasive bronchial carcinomas, ${ }^{67}$ raising the possibility that such viruses have an aetiological role in lung tumours. Moreover, butchers and meat cutters are unusually prone to infection by papilloma viruses, having a high prevalence of warts on their hands. ${ }^{8-11}$ Alternatively, a hazard could arise from exposure to polycyclic aromatic hydrocarbons or nitrites during the smoking and preservation of meat, or it might be that butchers are unusually heavy smokers.

To explore these ideas further, we have carried out a retrospective analysis of mortality among employees at two bacon factories and at a chain of abattoirs and meat distribution centres.

\section{Method}

The two bacon factories (companies A and B) in the south of England had each operated for more than 60 years. They slaughtered pigs, cured and processed bacon, and in addition produced sausages, pork, and (at company A only) pork pies. Other animals were not slaughtered, but small quantities of chilled beef

Accepted 15 February 1988 were brought in for use in sausage manufacture. The abattoirs and meat distribution centres (company C) were scattered across the north of England and had alf been in operation since 1954 or earlier. They handled mainly beef, pork, and lamb.

The study cohort was identified from personnel ando wages records, and comprised all men who had been employed since 1 January 1946 at company A, $\overrightarrow{\bar{O}}$ October 1952 at company B, or 1 January 1955 a? company $C$ and who by the end of 1971 had completed at least six months in jobs entailing regular contact with live animals or animal flesh. Subjects were tracect to the end of 1986 through the National Health Service Central Register and National Insurance Index, and death certificates were obtained for those who had died with the underlying cause of death coded to the ninth revision of the International Classification of diseases (ICD). Death rates from specific causes were compared with those of the national population by the person-years method with confidence intervals based. on the Poisson distribution.

\section{Results}

A total of 1610 men satisfied the entry criteria for the cohort: 431 at company $A, 160$ at company B, ando 1019 at company C. A total of 123 potential subjects were omitted because their employment records were? incomplete (unknown sex, job title, or dates of startingo and finishing jobs) and it was unclear whether they mee the conditions for inclusion. Five of the 1610 cohorn members could not be included in the analysis because 
Table 1 Observed and expected mortality: all subjects

\begin{tabular}{|c|c|c|c|}
\hline $\begin{array}{l}\text { Cause of death } \\
\text { (with ICD code) }\end{array}$ & $\begin{array}{l}\text { Deaths } \\
\text { observed }\end{array}$ & $\begin{array}{l}\text { Deaths } \\
\text { expected }\end{array}$ & $\begin{array}{l}\text { SMR (with } 95 \% \\
\text { confidence interval) }\end{array}$ \\
\hline All causes $(0-999)$ & 271 & $310 \cdot 3$ & $86(77-98)$ \\
\hline $\begin{array}{l}\text { Ischaemic heart disease }(410-414) \\
\text { Cerebrovascular disease }(430-438) \\
\text { Respiratory disease }(460-519) \\
\text { Digestive disease }(008-009,530-579) \\
\text { Injury and poisoning }(800-999) \\
\text { All neoplasms }(140-239)\end{array}$ & $\begin{array}{r}84 \\
17 \\
27 \\
4 \\
16 \\
87\end{array}$ & $\begin{array}{r}97.9 \\
26 \cdot 1 \\
37.6 \\
8 \cdot 0 \\
19 \cdot 2 \\
79 \cdot 8\end{array}$ & $\begin{array}{r}86(68-106) \\
65(38-104) \\
72(47-105) \\
50(14-127) \\
83(48-135) \\
109(87-134)\end{array}$ \\
\hline $\begin{array}{l}\text { Cancer of stomach (151) } \\
\text { Cancer of rectum (154) } \\
\text { Cancer of liver (155) } \\
\text { Cancer of lung, pleura, and mediastinum (162-163) } \\
\text { Cancer of prostate (185) } \\
\text { Hodgkins disease }(201) \\
\text { Non-Hodgkins lymphoma }(200,202) \\
\text { Myeloma (203) } \\
\text { Leukaemia (204-208) }\end{array}$ & $\begin{array}{r}13 \\
4 \\
3 \\
42 \\
3 \\
2 \\
1 \\
2 \\
3\end{array}$ & $\begin{array}{r}8 \cdot 0 \\
3 \cdot 6 \\
0 \cdot 5 \\
31 \cdot 7 \\
4 \cdot 0 \\
0 \cdot 8 \\
1 \cdot 5 \\
0 \cdot 8 \\
2 \cdot 1\end{array}$ & $\begin{array}{l}162(86-277) \\
111(30-284) \\
562(116-1642) \\
133(96-179) \\
76(16-221) \\
241(29-872) \\
68(2-379) \\
244(30-883) \\
142(29-416)\end{array}$ \\
\hline
\end{tabular}

Three deaths were from cancer of unspecified primary site, two from brain tumours, and one each from cancer of the oropharynx, oesophagus, colon, pancreas, larynx, penis, bladder, and kidney, and from polycythaemia vera.

their date of birth was unknown, and a further 15 could not be traced in National Health Service or National Insurance files and could only be followed up to their date of last employment. Thirty subjects had emigrated and were followed up to their date of embarkation.

Overall mortality in the cohort was less than in the national population (271 deaths observed, 310 expected), as was mortality from respiratory, digestive, cerebrosvascular, and ischaemic heart disease (table 1). There was an excess of deaths from cancer $(87$ observed, 80 expected), however, and in particular from tumours of the lung ( 42 observed, 32 expected) and stomach (13 observed, 8 expected). Small excesses were also found for cancer of the liver ( 3 observed, 0.5 expected) and lymphoma, myeloma, and leukaemia (8 observed, $5 \cdot 2$ expected).

The raised mortality from lung cancer was evident at companies $A$ and $C$, but not at company B (table 2 ). Adjustment of the expected numbers of deaths from lung cancer in proportion to the SMRs for lung cancer during 1968-78 in the local authority areas in which each factory or depot was situated led to an increase in the SMRs for companies $\mathrm{A}$ and $\mathrm{B}$ and a reduction for company $\mathbf{C}$ (table 2). Overall, the expected number of lung tumours was slightly reduced.

With help from management at each company we classified jobs according to whether they entailed regular exposure to live animals, warm (freshly slaughtered) meat, chilled meat, or the bacon process and its products. Table 3 shows the mortality from lung cancer for employees who were ever exposed in each of these categories. The risk was highest in those who worked with warm meat $(S M R=184)$ and whereas there was also an association with chilled meat (SMR $=142$ ), the latter disappeared when subjects with exposure to both warm and chilled meat were excluded (SMR = 90). A few jobs were ill defined and could not be assigned specific exposures, although a proportion probably did entail contact with warm meat. There were eight deaths from lung cancer among subjects who worked in ill defined jobs but were not definitely exposed to warm meat (SMR = 159).

Table 4 shows the mortality from lung cancer according to duration of exposure and time since first exposure, both to meat in general and specifically to warm meat. The excess of deaths was greatest at least ten years after first exposure but there was no clear

Table 2 Mortality from lung cancer by company

\begin{tabular}{|c|c|c|c|c|c|}
\hline \multirow[b]{2}{*}{ Company } & \multirow[b]{2}{*}{$\begin{array}{l}\text { Deaths } \\
\text { observed }\end{array}$} & \multicolumn{2}{|c|}{ Expected deaths from national rates } & \multicolumn{2}{|c|}{$\begin{array}{l}\text { Expected deaths from national rates with } \\
\text { local adjustment }\end{array}$} \\
\hline & & $\begin{array}{l}\text { Deaths } \\
\text { expected }\end{array}$ & SMR (with 95\% Cl) & $\begin{array}{l}\text { Deaths } \\
\text { expected }\end{array}$ & $S M R($ with $95 \% C l)$ \\
\hline $\begin{array}{l}\mathbf{A} \\
\mathbf{B} \\
\mathbf{C}\end{array}$ & $\begin{array}{r}13 \\
4 \\
25\end{array}$ & $\begin{array}{r}8 \cdot 8 \\
4 \cdot 4 \\
18 \cdot 5\end{array}$ & $\begin{array}{r}148(79-253) \\
91(25-234) \\
135(88-200)\end{array}$ & $\begin{array}{r}6 \cdot 9 \\
4 \cdot 0 \\
20 \cdot 2\end{array}$ & $\begin{array}{c}189(101-324) \\
99(27-254) \\
124(80-183)\end{array}$ \\
\hline All companies & 42 & $31 \cdot 7$ & $133(96-179)$ & $31 \cdot 1$ & $135(97-183)$ \\
\hline
\end{tabular}


Table 3 Mortality from lung cancer by exposure

\begin{tabular}{|c|c|c|c|c|}
\hline Exposure & $\begin{array}{l}\text { No of } \\
\text { subjects }\end{array}$ & $\begin{array}{l}\text { Deaths } \\
\text { observed }\end{array}$ & $\begin{array}{l}\text { Deaths } \\
\text { expected }\end{array}$ & SMR (with 95\% Cl) \\
\hline $\begin{array}{l}\text { Live animals } \\
\text { Warm meat } \\
\text { Chilled meat } \\
\text { Bacon process and products }\end{array}$ & $\begin{array}{l}65 \\
679 \\
731 \\
194\end{array}$ & $\begin{array}{r}2 \\
22 \\
16 \\
4\end{array}$ & $\begin{array}{r}2.0 \\
11.9 \\
11.3 \\
5.8\end{array}$ & $\begin{array}{l}101(12-365) \\
184(115-279) \\
142(81-231) \\
69(19-176)\end{array}$ \\
\hline
\end{tabular}

tendency for SMRs to rise with increasing duration of exposure.

When examined in relation to type and duration of exposure and time since first exposure, none of the other causes of death showed patterns to suggest an occupational hazard. Only two of the three deaths from liver cancer were due to hepatocellular tumours. The third was caused by cholangiocarcinoma in a patient with haemochromatosis.

\section{Discussion}

Our data support previous observations of high rates of lung cancer among butchers and slaughtermen in routine statistics. The possibility of confounding by tobacco cannot be put directly to test since we do not have first hand information about the smoking habits of our study population. Several features of the data, however, point to a true occupational hazard. Death rates from other tobacco related cancers (oral cavity, oesophagus, pancreas, larynx, kidney, and bladder) were not raised ( 5 deaths observed, $11 \cdot 3$ expected), and the SMR for respiratory diseases was only 72 . Moreover, the excess of lung cancer showed no tendency to disappear with allowance, albeit somewhat crude, for local variations in mortality. Smoking is thought to be a major determinant of the geographical differences in lung cancer within England and Wales. The concentration of the excess of lung cancer among subjects with exposure to recently slaughtered meat $(\mathrm{SMR}=184)$ was particularly impressive. A risk of this magnitude is unlikely to be explained simply by $\vec{\circ}$ a confounding effect of tobacco. ${ }^{12}$ The association with $\vec{\overrightarrow{ }}$ warm meat was most pronounced after a latency of at ${ }^{\omega}$ least ten years from first exposure, a pattern which again would support an occupational cause.

Against these observations must be weighed the lack of a clear gradient of risk with increasing duration of $\omega$ exposure to meat, and in particular to warm meat. $\vec{\infty}$ Also, in the only other published cohort study of meat $\infty$ workers, while there was an excess of lung cancer it윽 was more prominent among employees at meat pack- ing plants than among those working in abattoirs. ${ }^{13}$ Nor was an association with work in abattoirs apparent in a Swedish case-control study of lung $\triangle$ cancer carried out in a population of butchers ( $\mathbf{P} \overrightarrow{0}$ Gustavsson et al, XXII International Congress on Occupational Health, Sydney, 1987).

In view of these inconsistencies, the existence of an occupational hazard cannot be regarded as firmly established. If there is a risk, however, it seems unlikely@ to be related to the smoking or preservation of meat. ${ }^{\circ}$ In Britain only a small proportion of butchers work on such processes, and it would require a substantial rise in their risk of lung cancer to explain even a $25 \% \frac{}{5}$ increase in the rates for the occupation as a whole. A pattern of this sort would have been easily detectable in our study but was not apparent.

Infection by an oncogenic virus or viruses is a much more plausible explanation. Where the viruses respon-을 sible for butchers' warts have been typed, most have been human papilloma viruses, although in one study

Table 4 Mortality from lung cancer by duration of exposure and time since first exposure

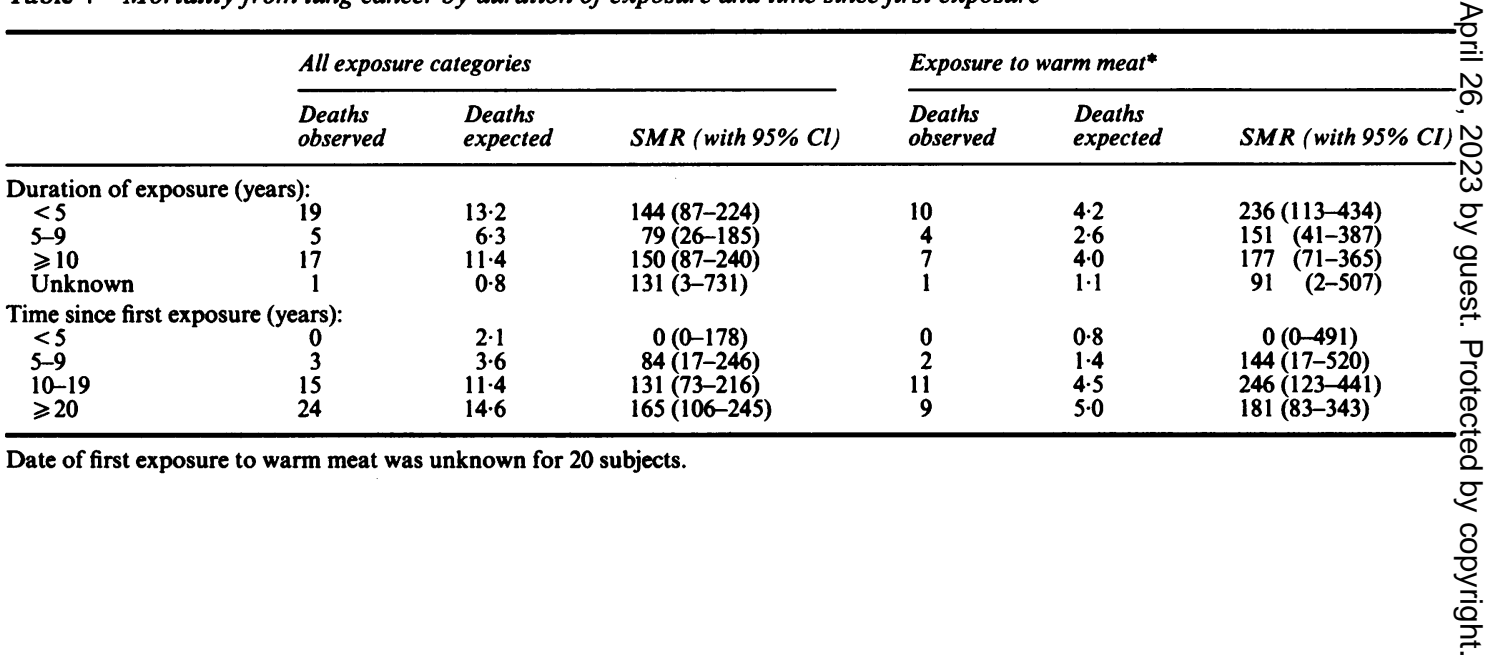


nine butchers were infected by a hitherto unknown papilloma virus. ${ }^{11 \text { is }}$ Possibly the environment of a slaughterhouse is favourable to the transmission of human papilloma virus not only from hand to hand but also through aerosol dispersion to the respiratory tract. Alternatively, lung tumours in butchers might be caused by a zoonotic infection. Bovine papilloma virus is a proved cause of alimentary cancer in cattle ${ }^{16}$ but a bovine virus could not explain the excess of lung cancer which we observed at company A where only pigs were slaughtered.

The one previously reported cohort study of meat workers indicated a possible risk of lymphatic cancer among employees at abattoirs. ${ }^{1314}$ Our data, however, give only weak support to this hypothesis. Of the three deaths from leukaemia in our study, one was from chronic lymphatic leukaemia but the other two were due to myeloid disease. Nor did we find any evidence of the postulated excess of prostatic cancer in butchers. ${ }^{17}$

Although not conclusive, our findings add weight to suspicions of a risk of lung cancer among butchers and slaughtermen. Further information is needed about smoking habits in different sections of the meat industry. In addition, future studies should concentrate on a possible viral aetiology for lung tumours in meat workers. Tumours occurring in butchers should be tested for viral DNA sequences, the agents responsible for butchers' warts should be more fully identified, and the risk of warts in relation to different activities in the meat industry should be examined.

We thank the participating companies and also the staff of the National Health Service Central Register and Department of Health and Social Security who helped to trace subjects.

\section{References}

1 Fox AJ, Lynge E, Malker H. Lung cancer in butchers. Lancet 1982;i:165-6.

2 Wynne Griffith G. Lung cancer in butchers. Lancet 1982;i:399.

3 Office of Population Censuses and Surveys. Occupational mortality: decennial supplement 1979-80, 1982-83. London: HMSO, 1986. (Series DS No 6.)

4 Lynge E, Andersen O, Kristensen TS. Lung cancer in Danish butchers. Lancet 1983;i:527-8.

5 Pegum JS. Lung cancer in butchers. Lancet 1982;i:561

6 Syrjanen KJ, Syrjanen SM. Human papillomavirus DNA in bronchial squamous cell carcinomas. Lancet 1987;i:168-9.

7 Byrne JC, Tsao M-S, Fraser RS, Howley PM. Human papillomovirus-II DNA in a patient with chronic laryngotracheobronchial papillomatosis and metastatic squamous-cell carcinoma of the lung. $N$ Engl J Med 1987;317:873-8.

8 Litt JA. Warts in meat cutters. Arch Dermatol 1969; 100:773.

9 De Peuter M, De Clercq B, Minette A, Lachapelle JM. An epidemiological survey of virus warts of the hands among butchers. Br J Dermatol 1977;96:427-31.

10 Wall LM, Oakes D, Rycroft RJG. Virus warts in meat handlers. Contact Dermatitis 1981;7:259-67.

11 Taylor SWC. A prevalence study of virus warts on the hands in a poultry processing and packing station. J Soc Occup Med 1980;30:20-3.

12 Axelson O. Aspects on confounding in occupational health epidemiology. Scand J Work Environ Health 1978;4:85-9.

13 Johnson ES, Fischman HR, Matanoski GM, Diamond E. Cancer mortality among white males in the meat industry. J Occup Med 1986;28:23-32.

14 Johnson ES, Fischman HR, Matanoski GM, Diamond E. Occurrence of cancer in women in the meat industry. Br J Ind Med 1986;43:597-604.

15 Orth G, Jablonska S, Favre M, et al. Identification of papillomaviruses in butchers' warts. $J$ Invest Dermatol 1981;76:97-102.

16 Jarrett WF. Bracken fern and papilloma virus in bovine alimentary cancer. Br Med Bull 1980;36:79-81.

17 James WH. Prostatic cancer, butchers and androgens. Lancet 1987;i:216-7. 